(2) Open Access Full Text Article

\title{
Can we save a follow-up appointment by leaving nylon sutures under plaster for 6 weeks?
}

This article was published in the following Dove Press journal:

Open Access Surgery

5 February 2010

Number of times this article has been viewed

\section{Randeep Aujla \\ Abhinav Gulihar \\ Andrew Chandraraj \\ Graham Taylor}

Orthopaedic Department, Glenfield Hospital, Groby Road, Leicester, England
Correspondence: RS Aujla

64 Anson Road, Shepshed, Leicester, LEI 29PU, UK

Tel +44 794469709 I

Email randeep.aujla@hotmail.co.uk
Background: The purpose of this study was to highlight the potential resource saving method of leaving nylon sutures under plaster for 6 weeks after forefoot surgery.

Methods: We gathered patient data from 72 cases of forefoot surgery over a 5-year period and analyzed the complications encountered. Only patients who required at least 6 weeks of plaster were included.

Results: There were two cases of wound infection and one of flap necrosis. The infection rates are comparable to previous studies into forefoot surgery infection rates. There was no difficulty in removing the sutures and scarring was not noted to be a problem.

Conclusions: Financial, convenience and time benefits could be obtained if this technique was in common practice.

Keywords: elective forefoot surgery, wound infections, wound complications, nylon sutures

\section{Introduction}

Suture removal post-operatively differs according to the part of the body undergoing surgery. The recommended time for suture removal is 4 days for face surgery, 7 days for upper limb surgery, 7 to 10 days for abdominal and chest surgery, and 10 to 14 days for foot surgery. ${ }^{1} 6$ weeks is a common period of time for plaster immobilization post-operatively in orthopedic surgery. An additional outpatient appointment for suture removal at 10 to 14 days is generally required, with a reapplication of plaster, to complete the 6 weeks. With sutures left in for 6 weeks, this additional follow-up appointment could be avoided.

The senior author has routinely left 3-0 nylon sutures under plaster for 6 weeks for various forefoot procedures. Interrupted sutures were used with careful placement of the knot to one side of the wound to reduce irritation.

We conducted a retrospective audit of patients following forefoot surgery who had skin closure with 3-0 nylon sutures, and who were immobilized in plaster for 6 weeks, to see whether leaving nylon sutures under plaster led to any increase in complication rates. Expected complications would include wound infection and difficulty removing sutures due to the increased time that the sutures wound stay in place.

\section{Methods}

All cases of forefoot surgery were obtained through operative lists between June 2002 and May 2007, and their individual operation notes were reviewed. We subsequently identified 72 cases that had sutures and plaster immobilization for 6 weeks. submit your manuscript $\mid$ www.dovepress.com

Dovepress
Open Access Surgery 2010:3 I-3

(C) 20I0 Aujla et al, publisher and licensee Dove Medical Press Ltd.This is an Open Access article which permits unrestricted noncommercial use, provided the original work is properly cited. 
These patients' notes were obtained and reviewed for any complications noted during routine follow-up at 6 weeks and beyond. Three doses of cefuroxime $(1500 \mathrm{mg}$ on induction and two $750 \mathrm{mg}$ doses post-operatively) were administered as antimicrobial prophylaxis in all cases, as per Hospital Trust guidelines at the time. All cases were included with no exclusion criteria. Full weight bearing was allowed immediately post-operatively. All 72 cases identified were followed up with no non-attenders. If there were any problems, before the planned 6 week follow-up, the patients were free to contact the clinic with a view to return early for plaster and suture removal, wound check and re-plastering. However this eventuality never occurred.

\section{Results}

In the 72 patients who had forefoot surgery there were a total of 137 wounds that were sutured. Surgical procedures performed included Mitchell's osteotomies, metatarsophalengeal/interphalengeal joint fusions and Stainsby procedures.

A breakdown of the complications found are presented in Table 1. The patient requiring the plaster splitting also developed delayed union. Bony union was achieved after a further 3 weeks in plaster. The patient who had flap necrosis was given antibiotics and achieved wound healing in 3 weeks. There was no clinical or microbiological evidence of infection found in this patient.

Suture removal was not found to be a problem in either the notes or by the nursing staff removing the sutures in the outpatient clinics. There were no reports of excessive scar formation in any patients.

Table I Leaving sutures under plaster for 6 weeks; Incidence of complications

\begin{tabular}{llll}
\hline Complication & & & Incidence \\
\hline Wound & $(\mathrm{n}=137)$ & $\begin{array}{l}\text { Infection } \\
\text { Slow healing } \\
\text { (diabetic) }\end{array}$ & 2 \\
& & Flap necrosis & $\mathrm{I}$ \\
Plaster problems & $(\mathrm{n}=97)$ & Pressure sores & 2 \\
& & Split & $\mathrm{I}$ \\
Bone & $(\mathrm{n}=130)$ & Delayed union & $\mathrm{I}$ \\
& & Non union & 0 \\
DVT/PE & $(\mathrm{n}=72)$ & & 0 \\
Sutures & $(\mathrm{n}=137)$ & Difficult removal & 0 \\
& & Retained & 0 \\
\hline
\end{tabular}

Abbreviations: $n$, number of patients; DVT/PE, deep vein thrombosis and pulmonary embolism.

\section{Discussion}

Nylon sutures are monofilament with a smooth surface to reduce the amount of friction on suture removal and lessen the risk of bacterial colonization in the suture material. The nylon is an inert material which produces little or no tissue reaction from the surrounding skin.

A search of the literature finds that infection rates in forefoot surgery vary, with results being: $0 \%, 0 \%, 0.47 \%, 1.6 \%$, $1.8 \%, 2.0 \%, 5.7 \%$ and $10 \% .^{2-9}$ Upon leaving in the sutures for 6 weeks, as opposed to their removal after a recommended 10 to 14 days, our study determined the infection rate was less than $1.5 \%$.

The forefoot is not a particularly important cosmetic area; nevertheless there was no report of excessive scarring in any of the patients notes or from the patients themselves.

Our study demonstrates there to be no increase in infection risk or problems in suture removal, if sutures remain in situ for 6 weeks, until the removal of the plaster. This would save resources like doctor/nurse/patient time and the cost of an additional visit to the clinic for both the health provider and the patient, as well as any further inconvenience to the patient. The current tariff paid by the primary care trust (PCT) to the NHS trusts is approximately $£ 80.00$ for any follow-up appointment. The approximate cost of plaster removal and application, including staff costs and the cost of materials is approximately $£ 25.00$. Hence, in total the cost of an extra outpatient appointment is approximately $£ 105.00$ per patient. Early removal of plaster in postoperative recovery, to remove the sutures, can also increase the risk of damaging any surgical work performed (eg, disturbing an osteotomy or fusion site before bony union).

\section{Conclusion}

We conclude that by leaving nylon sutures in place for 6 weeks under a plaster cast, after forefoot surgery, causes no additional risk to the patient. The financial and time benefits could be obtained if this technique was used as common practice.

\section{Disclosures}

The authors report no conflicts of interest with this work.

\section{References}

1. Garden OJ, Bradley AW, Forsythe J. Principles and Practice of Surgery. 4th edition. London: Churchill Livingstone; 2002. p.142-143.

2. Briggs TWR, Smith P, Mcauliffe TB. Mitchell's Osteotomy using internal fixation and early mobilisation. $J$ Bone Joint Surg Br. 1992;74(1):137-139.

3. Agoropoulos Z, Efstathopoulos N, Mataliotakis J, et al. Long-term results of first metatarsophalangeal joint fusion for severe hallux valgus deformity. J Foot Ankle Surg. 2001;7:9-13. 
4. Taylor GJS, Bannister GS, Calder S. Perioperative wound infection in elective orthopaedic surgery. J Hosp Inf. 1990;16:241-247.

5. Zgonis T, Jolly GP, Garbalosa JC. The efficacy of prophylactic antibiotics in elective foot and ankle surgery. J Foot Ankle Surg. 2004;43(2): 97-103.

6. Tan MY, Seow KH, Tay BK. The Mitchell distal metatarsal osteotomy for hallux valgus-the Singapore General Hospital experience. Singapore Med J. 1998;39(12):547-550.
7. Miller JW. Distal first metatarsal displacement osteotomy: its place in the schema of bunion surgery. J Bone Joint Surg Am. 1974;56:923-931.

8. Chana GS, Andrew TA, Cotterill CP. A simple method of arthrodesis of the first MTP joint. J Bone Joint Surg Br. 1984;66-B(5):703-705.

9. Calder JD, Hollingdale JP, Pearse MF. Screw versus suture fixation of Mitchell's osteotomy: A prospective, randomized study. J Bone Joint Surg. 1999;81:621-624

\section{Publish your work in this journal}

Open Access Surgery is an international, peer-reviewed, open access journal that focuses on all aspects of surgical procedures and interventions. Patient care around the peri-operative period and patient outcomes post surgery are key topics. All grades of surgery from minor cosmetic interventions to major surgical procedures are covered. Novel techniques

Submit your manuscript here: http://www.dovepress.com/open-access-surgery-journal

\section{Dovepress}

and the utilization of new instruments and materials, including implants and prostheses that optimize outcomes constitute major areas of interest. The manuscript management system is completely online and includes a very quick and fair peer-review system. Visit http://www.dovepress.com/ testimonials.php to read real quotes from published authors. 